\title{
PENGARUH CITRA MEREK (BRAND IMAGE) DAN KEPUASAN WISATAWAN TERHADAP LOYALITAS WISATAWAN PADA BALI ADVENTURE RAFTING
}

\author{
Ardilla Nathaurisia \\ Yayu Indrawati \\ I GPB. Sasrawan Mananda \\ Email : ardilla.tan@gmail.com \\ PS. S1 Industri Perjalanan Wisata \\ Fakultas Pariwisata UNUD
}

\begin{abstract}
With loyalty and high power of buying. Research impact of brand image and guest satisfaction on customer loyalty is important to do in order to obtain an explanation of the relationship between brand image and customer satisfaction on customer loyalty. The purpose of this study is 1) to identify the circumstance brand image on customer loyalty. 2) to identify the circumstance customer satisfaction on customer loyalty. 3) to determine the circumstance brand image and customer satisfaction on customer loyalty. This research was conducted at Bali Adventure Rafting. Result shows that branding and customer satisfaction has a significant effect on customer loyalty in Bali Adventure Rafting with result $41,7 \%$. This result is obtained from the value of determination $D x$ $100 \%=0,417 \times 100 \%=41,7 \%$. This means that the brand image and customer satisfaction contributing positively to customer loyalty of rating of $41,7 \%$ and the remaining $58,3 \%$ is influenced by others factors such as costumers satisfaction, marketing strategy.
\end{abstract}

Keywords: Brand Image, Customer Satisfaction, and Loyalty.

\section{PENDAHULUAN}

Memuaskan pelanggan merupakan salah satu tujuan setiap perusahaan. Perusahaan jasa ataupun produk menciptakan dan mempertahankan pelanggan hendaknya menjadi hal yang diutamakan. Mempertahankan pelanggan lama lebih menghemat biaya promosi daripada mendatangkan pelanggan baru. Kepuasan pelanggan diartikan sebagai respon yang kuat terhadap pengalaman mengkonsumsi produk yang sesuai harapan. Kepuasan konsumen adalah hasil dari perbandingan antara harapan dengan kenyataan. Apabila konsumen merasa puas dengan apa yang dikonsumsinya maka akan timbul kesetian terhadap produk yang dibelinya. Loyalitas tidak hadir begitu saja, dibutuhkan kiat-kiat dalam hal mengelola untuk menghadirkan loyalitas. Perusahaan seharusnya dapat mengenal kebutuhan dan harapan konsumen dimasa sekarang dan akan datang. Salah satu jalan dalam meraih keunggulan knmnetici dalam memnertahankan lovalitas baik dimata konsumen. Dengan adanya kesetiaan yang tinggi dan daya minat beli yang tinggi akan memberikan dampak terhadap peningkatan penjualan perusahaan. Dengan kajian diatas maka dilakukan penelitian yang memfokuskan pada pengaruh citra merek dan kepuasan wisatawan terhadap loyalitas wisatawan pada produk Bali Adventure Rafting.

\section{TINJAUAN KONSEP}

Menurut Kotler (dalam Ogi Sulistian. 2011) mendefinisikan citra merk merupakan sekumpulan kepercayaan dari seseorang akan suatu merek. Citra merek menjadi syarat untuk merek yang kuat. Citra merek terdiri dari citra pembuat, citra pemakai, dan citra produk.

Berasal dari bahasa latin "satis" dengan arti cukup baik dan "facio" yang berarti melakukan jadi arti kata kepuasan adalah upaya memuaskan. Apabila dilihat dari sudut pandang pelanggan istilah kepuasan menjadi begitu knmnleks Komnonen utama dari kenuasan 
Ketiga komponen ini memiliki pengaruh yang cukup besar dalam mengartikan kepuasan itu sendiri.

Loyalitas konsumen merupakan konsistensi konsumen dalam bertahan dan melakukan konsumsi produk atau jasa secara konsisten dimasa akan datang, walaupun dipengaruhi oleh keadaan, atau usaha pemasaran lainnya yang mengakibatkan perubahan perilaku konsumen. Menurut Griffin (2005) seorang konsumen dikatakan setia apabila konsumen tersebut melakukan konsumsi ulang paling sedikit dua kali pada waktu tertentu.

\section{METODE}

Model penelitian menggunakan dua variabel independen yaitu citra merek dan kepuasan pelanggan dengan satu variabel dependen yaitu loyalitas konsumen. Berdasarkan pokok permasalahan maka hipotesis yang dapat disampaikan pada riset ini ialah: H1 : Citra merek berdampak signifikan terhadap loyalitas wisatawan, H2 : Kepuasan wisatawan berdampak signifikan dengan loyalitas wisatawan, H3 : Terdapat pengaruh citra merek dan kepuasan wisatwan terhadap loyalitas wisatawan.

Penelitian ini dilakukan di Bali Adventure Rafting, Ubud. Penelitian ini focus pada dua variabel independen yaitu citra merek dan kepuasan pelanggan terhadap variabel dependen loyalitas wisatawan yang nantinya memiliki output untuk mengetahui pengaruh dari citra merek dan kepuasan wisatawan terhadap loyalitas wisatawan.

Menyebarkan angket serta observasi merupakan teknik pengumpulan data yang digunakan dalam riset ini. Teknik penentuan sample ditentukan dengan metode purposive sampling. Penelitian ini menggunakan penelitian kuantitatif deskriptif dan menggunakan skala likert sebagai pengukur atau pemberi skor disetiap indikator. Dengan Model dari J.Supranto dengan mengalikan 5 sampai 10 indikator dalam kuesioner menghasilkan sampel sebanyak 70 sampel, yang didapat dengan mengalikan 5 dengan 14 indikator yang ada pada kuesioner. Data yang telah terkumpul nantinya di analisis dengan menggunakan analisis regresi berganda.

\section{PEMBAHASAN}

\section{Karakteristik Responden}

Bali Adventure Rafting merupakan sebuah perusahaan yang melayani jasa arung jeram yang terpusat di Sungai Ayung, Ubud. Bali Adventure Rafting ini terletak di Desa Kedewatan, Ubud. Dalam penelitian ini karakteristik responden diteliti dari jenis kelamin wisatawan (laki-laki dan perempuan) dan umur wisatawan (12-30 tahun, $21-30$ tahun, 31 - 40 tahun dan $>40$ tahun).

\section{Pengujian Instrumen Uji Validitas}

Berdasarkan hasil dari uji validitas dapat diketahui bahwa instrumen pada semua variabel riset ini valid dilihat dari nilai korelasi semua instrumen $>0,3$ dan bisa digunakan dalam pengujian hipotesis. Uji validitas dalam riset ini dibantu dengan program SPSS for Windows 17.

\section{Uji Reliabilitas}

Variabel dikatakan reliabel bila nilai koefisien alpha $(\alpha)>0,6$ dari cronbach's alpha (Ghozali:2002). Apabila koefisien alpha lebih besar dari 0,60, jika nilai koefisien alpha $<0,60$ maka variabel itu tidak reliabel.

\section{Uji Asumsi Klasik}

Statistic parametric digunakan sebagai alat uji asumsi klasik dalam model regresi berganda untuk menguji apakh data telah terdistribusi secara merata. Uji asumsi klasik terdiri dari

1. Uji Normalitas

Merupakan pengujian statistik dalam penentuan suatu data berdistribusi normal atau tidak. Berdasarkan hasil output diperoleh Asymp.Sig.(2-tailed) sebesar $0,967>$ alpha 0,05 sehingga data ini dapat dikatakan berdistribusi normal.

2. Uji Autokorelasi

Dilakukan untuk menguji apakah terdapat hubungan antara data observasi yang diurutkan menurut waktu. Besaran DubinWatson (D-W) digunakan untuk pengujian ini.

3. Uji Multikolinearitas

Dilakukan untuk menguji apakah pada model regresi terdapat hubungan dengan variabel bebas. Dengan melihat nilai tolerance dan variance inflation factor $(\mathrm{VIF})<10$, maka data tersebut tidak menoalami multiknlinearitas Rerdasarkan 
tolerance variabel bebas $<10$ persen $(0,1)$ dan semua variabel bebas mempunyai VIF kurang dari 10 , sehingga tidak terjadi multikolinearitas antar variabel bebas dalam model ini.

4. Uji Heterodastisitas

Dilakukan untuk menguji apakah model regresi memiliki perbedaan varian dari residual satu pengamatan ke pengamatan yang lain. Berdasarkan hasil uji heterodastisitas dimana variabel independen adalah absolute residual diperoleh bahwa seluruh variabel dependen terbebas dari heterodastistas, karena nilai signifikansi masing-masing variabel $>0,05$.

\section{Pengaruh Citra Merek (brand image) Terhadap Loyalitas Wisatawan}

Analisis pengaruh citra merek (X1) terhadap variabel loyalitas wisatawan (Y) studi kasus pada Bali Adventure Rafting. Berdasarkan hasil analisis regresi linear berganda dengan program SPSS, maka diperoleh nilai $\mathrm{t}$ hitung sebesar 3,980. Berdasarkan hasil perhitungan uji $\mathrm{t}$ diperoleh hasil yaitu $\mathrm{t}$ hitung $>\mathrm{t}$ tabel $(3,980>1,671)$, maka Ho ditolah dan Hi diterima. Jadi citra merek berdampak positif dan signifikan secara parsial dengan loyalitas wisatawan.

\section{Pengaruh Kepuasan Wisatawan terhadap Loyalitas Wisatawan}

Analisis kepuasan wisatawan (X2) terhadap variabel loyalitas wisatawan $(\mathrm{Y})$ pada studi kasus Bali Adventure Rafting secara parsial. Dari output analisis regresi linear berganda dalam program SPSS, maka diperoleh nilai t hitung sebesar 6,072. Berdasarkan hasil perhitungan uji t diperoleh hasil yaitu t hitung $>$ t tabel $(6,072>1,671)$, maka Ho ditolak atau Hi diterima. Koefisien regresi variabel citra merek adalah sebesar 6,072 yang memiliki arti bahwa setiap peningkatan kepuasan wisatawan, akan mengakibatkan peningkatan loyalitas wisatawan.

\section{Pengaruh Citra Merek dan Kepuasan Wisatawan Terhadap Loyalitas Wisatawan Analisis Korelasi Berganda}

Berdasarkan data yang telah diolah didapatkan besarnya nilai $\mathrm{R}$ adalah 0,646. Berdasarkan Sugiyono (2008) dengan metode Pearson didapat kriteria tinggi rendahnya huhunoan maka $R$ sehesar 0646 terletak korelasinya kuat. Ini berarti kedua variabel citra merek dan kepuasan wisatawan secara bersama-sama berhubungan simultan dengan variabel terikat loyalitas wisatawan.

\section{Analisis Determinasi}

Dilihat dari output analisis regresi berganda didapat nilai koefisiensi determinasi (D) sebesar $0,417 \times 100 \%=41,7 \%$ yang artinya citra merek dan kepuasawan wisatawan memiliki kontribusi senilai $41,7 \%$ terhadap loyalitas wisatawan dan sisanya $58,3 \%$ dipengaruhi oleh faktor lain.

\section{Uji Signifikansi}

Hipotesis kerjanya adalah : Ho: $\beta 1=\beta 2$ $=0$, berarti : "Tidak terjadi pengaruh antara citra merek dan kepuasan wisatawan dengan loyalitas wisatawan", $\mathrm{Ha}: \beta 1>0$ dan $\beta 2>0$, berarti : "Terjadi pengaruh positif dan signifikan antara citra merek dan kepuasan wisatawan terhadap loyalitas wisatawan".

Dalam pengujian ini digunakan $\mathrm{F}$ tabel $=$ $\mathrm{F}(\alpha ; \mathrm{dfn} / \mathrm{dfd})$. Besarnya $\alpha$ atau taraf kepercayaan yang dipakai adalah sebesar 5\%. Degrees of freedom numerator $(\mathrm{dfn})=\mathrm{k}-3$, dan degrees of denominator $=(\mathrm{dfd})=\mathrm{n}-2-1=70-2-1=67$. Besarnya $F(\alpha ; \mathrm{dfn} / \mathrm{dfd})$ adalah 3,15 .

\section{SIMPULAN \\ Simpulan}

Berdasarkan penelitian di atas dapat ditarik kesimpulan bahwa citra merek dan kepuasan pelanggan mempunyai pengaruh yang signifikan terhadap loyalitas wisatawan studi kasus pada Bali Adventure Rafting sebesar $41,7 \%$. Ini artinya citra merek dan kepuasan wisatawan memberikan sumbangan yang positif terhadap loyalitas wisatawan dan $58,3 \%$ nya dipengaruhi oleh faktor lain.

\section{Saran}

Berhubung citra merek dan kepuasan wisatawan memiliki kontribusi yang positif terhadap loyalitas wisatawan, pihak manajemen Bali Adventure Rafting hendaknya memperhatikan citra merek dan selalu berupaya untuk meningkatkan kepuasan wisatawan. Persentase kontribusi citra merek dan kepuasan wisatawan masih dibawah 50\% maka dipandang masih perlu dikaji faktor lain yang dapat mempengaruhi loyalitas wisatawan studi kasus pada Bali Adventure Rafting. 
Aryani Dwi, Rosinta Febrina. 2010. Pengaruh Kualitas Layanan Terhadap Kepuasan Pelanggan dalam Mebentuk Loyalitas Pelanggan. Jurnal Ilmu Administrasi dan Organisasi. ISSN 0854-3844. Hal: 114126

Ghozali, Imam. 2006. Aplikasi Analisis Multivariate dengan Program SPSS. Badan Penerbit Universitas Semarang.

Gujarati, Damodar. 2006. Ekonometrika Dasar. Jakarta: Erlangga.

Griffin, Jill. 2003. Customer Loyalty. Edisi Revisi dan Terbaru Jakarta : Erlangga.

Griffin, Jill. 2005. Customer Loyalty How To Earn It How To Keep It. Edisi Revisi. Jakarta: Erlangga.

Kasuma Dewi, Andri Gus, Yonaldi Sepris. 2012 Pengaruh Iklan, Citra Merek, dan Kepuasan Konsumen Terhadap Loyalitas Konsumen Dalam Menggunakan Vaseline Hand and Body Lotion Di Kota Padang (Studi Kasus Di PT.Unilever Cabang Padang). Jurnal Manajemen dan Kewirausahaan, Vol 3. No 2. ISSN: 2086-2031. Hal: 11-29.

Kotler, Philip. 2002. Manajemen Pemasaran, Edisi Milenium. Jakarta : Prelindo

Subagyo Pangestu dan Djarwanto PS, 2005, Statistik Induktif, Edisi 5, Penerbit BPFE, Yogyakarta.

Supranto, J. 2001. Pengukuran Tinggi Kepuasan Pelanggan. Jakarta: Rineka Cipta.

Sugiyono. 2008. Metode Penelitian Bisnis. Bandung: Alfabeta.

Sugiyono. 2011. Metode Penelitian Kuantitatif Kualitatifdan R\&D. Bandung: Alfabeta.

Sulistian, Ogi. 2011. Pengaruh Brand Image Terhadap Loyalitas Pelanggan Rokok Gudang Garam Filter Kuningan: Fakultas Ekonomi Universitas Kuningan.

Suyana Utama, Made. 2007. Aplikasi Analisis Kuantitatif. Denpasar: Sastra Utama.

Tjiptono, Fandy, Chandra Gregorius. 2004. Service, Quality \& Satisfaction. Yogyakarta: Penerbit Andi.

Wirawan, Nata. 2002. Statisk Ekonomi 2.

Keraras Emas. Denpasar. 